Table shewing the comparative value of different light apparatus.

\begin{tabular}{|c|c|c|c|c|c|}
\hline Description of Light & $\begin{array}{l}\text { Eresnel's revol- } \\
\text { ving beams, } \\
\text { first order. }\end{array}$ & $\begin{array}{l}\text { Revolving beans } \\
\text { rrom } 24 \text { Parabs- } \\
\text { loidal Reflectors, } \\
6 \text { faces, } 4 \text { in each } \\
\text { face. }\end{array}$ & $\begin{array}{l}\text { Revolving beams } \\
\text { from } 18 \text { Para- } \\
\text { boloidal Reflec- } \\
\text { tors, } 6 \text { faces, } \\
\text { reflectors in each } \\
\text { face. }\end{array}$ & $\begin{array}{l}\text { Revolving } \\
\text { beams } \\
\text { from } 20 \mathrm{~Pa} \\
\text { raboloidal } \\
\text { Reflectors, } \\
5 \text { faces, } 4 \\
\text { reflectors } \\
\text { in each } \\
\text { face. }\end{array}$ & $\begin{array}{l}\text { Reroloing } \\
\text { beams } \\
\text { from } 20 \text { pe } \\
\text { rabolotan } \\
\text { Reflectors } \\
5 \text { faces; } \\
\text { reflectorn } \\
\text { in each } \\
\text { face. }\end{array}$ \\
\hline Oil used in 12 hrs. & 16 Pints & 18 Pints. & 14 Pints. & 15 Pints. & 15 Pints. \\
\hline $\begin{array}{l}\text { to revolving } \\
\text { prism. } \\
\text { Time of revolu- }\end{array}$ & 8 & 6 & 6 & 5 & b \\
\hline $\begin{array}{l}\text { tion of entire } \\
\text { anparatus in } \\
\text { seconds. }\end{array}$ & $480 \mathrm{~s}$ & $360 \mathrm{~s}$ & $360 \mathrm{~s}$ & $360 \mathrm{~s}$ & $300 *$ \\
\hline $\begin{array}{l}\text { Duration of in- } 9 \\
\text { tense light on } \\
\text { aeaman's eye. }\end{array}$ & $\begin{array}{l}9 \text { sec. in all } \\
\text { increasing: } \\
\text { full, and di } \\
\text { minishing. }\end{array}$ & $\begin{array}{l}22 \text { sec. being } \\
\text { abrupt in } \\
\text { appearance } \\
\text { and disap- } \\
\text { pearance, in } \\
\text { will be finl } \\
\text { fol } 20 \text { sec. }\end{array}$ & $\begin{array}{l}22 \text { sec., eame } \\
\text { as No. } 2 \text {, but } \\
\text { not so strong } \\
\text { a light. }\end{array}$ & $\begin{array}{l}22 \text { sec., } \\
\text { tameas } \\
\text { before, } \\
\text { as strong } \\
\text { as No.2. }\end{array}$ & $18 a$ \\
\hline $\begin{array}{l}\text { Time between } \\
\text { appearanceand } \\
\text { re-appearance } \\
\text { of beam. }\end{array}$ & $60 \mathrm{~s}$ & $60 \mathrm{~s}$ & $60 \mathrm{~s}$ & $72 \mathrm{~s}$ & 60 영 \\
\hline $\begin{array}{l}\text { Duration of dark- } \\
\text { ness interven- } \\
\text { ings. } \\
\text { Will be seen as a }\end{array}$ & $50 s$ & $38 \mathrm{~s}$ & $38 \mathrm{~s}$ & $50 \mathrm{~s}$ & $48 \mathrm{~s}$ \\
\hline $\begin{array}{l}\text { permanent light: } \\
\text { with beams at } \\
\text { distance from } \\
\text { L. H., of, sity }\end{array}$ & 6 or 8 miles. & 6 or 8 miles & 6 or 8 miles. & $\begin{array}{l}6 \text { or } 8 \\
\text { miles. }\end{array}$ & $\begin{array}{l}6 \text { or } 8 \\
\text { miles. }\end{array}$ \\
\hline $\begin{array}{l}\text { Distance at which } \\
\text { the intense light } \\
\text { will be visible }\end{array}$ & $\begin{array}{l}\text { From horizon } \\
24 \text { miles. } \\
\text { From top- } \\
\text { mast, from } \\
5 \text { to } 20 \text { miles } \\
\text { further. }\end{array}$ & \multicolumn{4}{|c|}{$\begin{array}{l}\text { Same distance, but clearer in case of thick } \\
\text { weather. }\end{array}$} \\
\hline
\end{tabular}

Alexander Gopoon.

22, Fludyer Street, Whitehall, April 18th, 1846.

\title{
Canal Across the Isthmus of Panana.
}

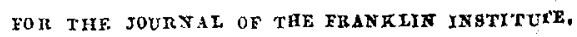

The subject of improved communications between the two sides of the American continent, always interesting, is becoming more so every year.

We are indebted to Persifor Frazer, Esq., for sending us from Paris a copy of the report of Napoleon Garella, an engineer appointed by the French government, under the auspices of M. Guizot, to make a scientific survey of the Isthmus of Panzma, in reference to the construction of a ship canal between the Atlantic and Pacific oceans. The survey was made in 1844.

VOL. XI, 3RD SERIES,-NO. 6.-JUNE, 1846. 
This report, unlike most other publications on the subject, bears evidence of professional ability, careful study, and impartiality in setting forth the facts of the case. It is our intention in the next number of the Journal to commence the publication of the most important portions of it, and we now give the following summary of results.

The whole length of the proposed canal, from its northern outlet on the Atlantic near Chagres, to its southern outlet on the Pacific near Panama, is $47 \frac{1}{2}$ miles; and the distance in a straight line between the two towns is 40.68 miles. The mean level of the Pacific, at tho terminus of the line, is 92 feet above that of the Atlantic, the highest tides in the former rising 20 feet, and in the latter only 16 inches.

On account of the height of the intervening ground, the popular idea of a thorough-cut is out of the question. The natural summit is ten miles from the Pacific ocean, and 460 feet above it. It is proposed to reduce the summit to a height of 135 feet above the sea, by a tunnel $3 \frac{1}{3}$ miles in length, and to overcome the remaining clevation by means of 35 lift locks, 17 upon the southern and 18 upon the northern side of the summit. The tunnel is to be through rock, in the form of a gothic arch, its height being 121 feet, and its extreme width, with a towing path, $69 \frac{x}{2}$ feet. By such a reduction of the summit it is shown that an ample supply of water can be commanded, and a thorough-cut may be substituted for the tunnel, but at an increased expense.

The estimates are made for a canal of dimensions suitable for ships of 1200 tons burthen. The lock chambers are to be 210 feet long and $46 \frac{1}{2}$ feet wide. The width of the canal on the bottom 66 feet, at the water surface 148 feet, and the depth 23 feet. The total cost of the work, including its terminal harbors, is estimated at about twentyfive millions of dollars, and the time required to complete it ten years. The construction of a canal large enough to pass heavy freight in large vessels withont transhipment, M. Garella considers to be an object of the first importance; but if, on account of the expense, it should be given up or postponed, he then recommends a macadamized road, which could readily be made, and would furnish great facilities for the transit of passengers and valuable merchandize across the isthmus.

For the purpose of comparison, it may be well to mention that a proposed rouls between the two oceans, by the way of the Lake of Nicaragua, was surveyed in 1838 by an English gentleman named Bailey, employed by the government of Central America. His results are given in Stephens' Incidents of Travel. 'The natural summit, on his line, is four miles from the Pacific, and 616 feet above it. The fall from the suramit to the Lake of Nicaragua, is 487 feet in 12 miles, and the whole aistance from sea to sea is 125 miles.

The report of M. Garella contains notices of the labors of those who have preceded him in investigating or reporting upon the project of a canal to connect the tro oceans; and, in reference to the line by the Isthmus of Panama, his investigations appear to be far more complete than those of any of his predecessors.

S. W. R. 